\title{
The occurrence of summer diapause in the large white butterfly Pieris brassicae (Lepidoptera: Pieridae): A geographical perspective
}

\author{
Hubert R. SPIETH ${ }^{1}$, Ulrich PÖRSCHMANN ${ }^{2}$ and CARola TEIWES ${ }^{1}$ \\ ${ }^{1}$ Department of Animal Ecology and ${ }^{2}$ Department of Animal Behavior, University of Bielefeld, Morgenbreede 45, \\ D-33615 Bielefeld, Germany; e-mail: hubert.spieth@uni-bielefeld.de
}

Key words. Lepidoptera, Pieridae, aestivation, geographic pattern, heritability of diapause, Pieris brassicae, photoperiodic response

\begin{abstract}
At the south western border of its extensive distribution, the multivoltine large white butterfly, Pieris brassicae L., is exceptional in undergoing summer diapause or aestivation. In all other regions investigated, $P$. brassicae pupae only hibernate. The transitional zone from non-aestivating to aestivating populations is a geographically stable region south of the Pyrenees. The restriction of this response to this region cannot be accounted for in terms of genetics as aestivation is intermediately inherited, with the heritability $\left(\mathrm{h}^{2}\right)$ of aestivation in inbreeding lines between 0.35 and 0.77 . Two hypotheses are presented to explain why this species does not aestivate in more northern regions. First, aestivation is a behaviour that serves to synchronize generations in areas where this species produces a high number of generations per year. Second, aestivation reduces the incidence of parasitism suffered by the butterfly by desynchronizing its life cycle from that of its main parasitoid, Cotesia glomerata. The two hypotheses are not mutually exclusive and both seem to be adaptive where the species is multivoltine.
\end{abstract}

\section{INTRODUCTION}

Insects have evolved numerous life history strategies, which have enabled them to adapt their ontogeny and reproduction to seasonal changes in their environment (Masaki, 1996; Tauber et al., 1986; Musolin \& Saulich, 1999; Danks, 2002, 2006a). In terms of population development, the diversity in life history traits divides insect species into two categories (Danks, 2001): First, those with only one generation (univoltinism) and second those with several generations per year (multivoltinism). Underlying this classification are differences in the utilisation of the available natural resources throughout the year. The two strategies differ fundamentally in life cycle plasticity. Univoltine species are closely adapted to certain seasonal conditions, a mechanism associated with the optimal exploitation of seasonally limited food resources or for limiting competition with other species (Danks, 2006b). In typically univoltine species, a developmental arrest occurs at a fixed stage in ontogeny and is induced by endogenous mechanisms (Koštál, 2006). It results in an obligatory diapause that normally is not terminated until the next season. In contrast, multivoltine species rely on exogenous factors such as environmental signals to trigger a developmental arrest. This has the advantage that species may respond flexibly to varying life conditions (Bradshaw \& Holzapfel, 2007), producing a continuous series of generations until environmental conditions force a developmental arrest. This process is termed facultative diapause and enables a species to adjust the number of generations to local conditions and it further allows to exploit the whole period for which circumstances remain favourable in different geographical regions (Spieth, 1985; Gomi, 1997; Takeda, 1997).
Hence, obligate and facultative diapause are fundamentally different life history traits.

For multivoltine species there are many cases of hibernation diapause induced by photoperiod and temperature at the end of the growing season (for reviews see: Danilevskii, 1965; Beck, 1980; Danks, 1987; Veerman, 1992; Zaslavski, 1988; Numata, 2004). If the food supply is reduced during the growing season by heat and drought, an arrest in development in summer, termed aestivation diapause, may be advantageous.

In those species which show hibernation as well as aestivation diapause, these developmental arrests mostly occur in different ontogenetic stages and are often induced by distinct environmental factors (Wiklund et al., 1983; Takeda, 1997; Xue \& Kallenborn, 1998; Wang et al., 2007). Currently only a few species are known to undergo a photoperiod-induced facultative diapause in winter and summer in the same ontogenetic stage (Masaki, 1980; Hodek et al., 1984; Held \& Spieth, 1999). Depending on day length, these species respond by switching to one of three different modes of development: hibernation, aestivation or direct development. These cannot be classified in a classical long-day / short-day scheme but are based on a more complex mechanism of the involved photoperiodic clock (Spieth et al., 2004; Spieth \& Strauß, 2010).

Among the species that exhibit multiple responses, the cabbage moth, Mamestra brassicae, is the best investigated. In Japan (Masaki, 1968; Grüner \& Masaki, 1994) and France (Grüner \& Sauer, 1988; Sauer \& Grüner, 1988), the entire population either undergos aestivation diapause under long-day or hibernation diapause under short-day conditions in the pupal stage. Other species in which all the individuals show this dual photoperiodic response are the cabbage butterfly, Pieris melete, in 
China (Xue et al., 1997) and the large white butterfly, Pieris brassicae (Spieth et al., 2004).

Pieris brassicae exhibits a specific geographical pattern in the incidence of summer diapause. Specifically, only the subpopulation from the Southern Iberian Peninsula undergoes facultatively either aestivation or hibernation diapause (Held \& Spieth, 1999). All other populations of this species investigated, from Western Europe to the Amur region, only undergo hibernation diapause, independent of the local climatic conditions. From an ecological and biogeographical point of view, the geographical pattern in this response is unusual. Mamestra brassicae in Japan and Europe shows a clinal gradient in the incidence of aestivation, increasing from northern temperate to southern hot and dry summer conditions. This type of pattern is quite normal for a facultative photoperiodic response (Danilevskii, 1965; Zaslavski, 1988).

It is unclear why $P$. brassicae, which is widely distributed throughout the palaearctic, only undergoes summer diapause in a very restricted area. The following hypotheses are proposed to explain this phenomenon: (1) In areas where the climatic conditions are favourable this butterfly can complete nine generations per year. Under these specific circumstances aestivation may serve to synchronize the generations with periods of more favourable conditions (Spieth, 2002). (2) The large white butterfly is heavily parasitized and the percentage parasitism increases seasonally from generation to generation. An interruption in the generation sequence in summer markedly reduces the parasitic load (Spieth \& Schwarzer, 2001; Pörschmann \& Spieth, 2011). Both strategies could benefit the species. However, why this behaviour has not evolved in other populations of $P$. brassicae that experience similar hot and dry summer climates is unknown.

In this study, the geographical pattern in the incidence of hibernation and aestivation recorded for $P$. brassicae is determined. In addition, whether aestivation evolved recently and is likely to become more widely distributed in other warm regions in the future is investigated. In this context, in- and out-breeding experiments were conducted to determine the heritability of aestivation and the likelihood of the spread of genes for aestivation by introgressive hydridization into exclusively hibernating populations.

\section{MATERIAL AND METHODS}

Eggs and caterpillars of $P$. brassicae were collected in Southern Europe in different years. The times and localities were as follows: Banyuls sur Mer (Southern France), several times in the years 1986-1995; Sotogrande (Southern Spain), April 1993, March 1994 and September 1997; Castellón (Southern Spain), April 1996, September 2003 and May 2004; along an East to West transect in Northern Spain, September / October 1998 and April 2000; Lisbon (Portugal), September 1996, April and September 1997; Livorno, Giglio and Policastro (Italy), September 1997.

For each population a photoperiodic response curve was generated in order to determine whether aestivation was triggered by a particular day length. The diapausing stage for both hibernation and aestivation is the pupa and the photosensitive stage the caterpillar. Since caterpillars of $P$. brassicae are photosensi- tive during their entire larval life (Spieth, 1995) and the larvae that were collected in the field were exposed to naturally changing light and temperature conditions for an unknown period, the photoperiodic response was always that of the F1 generation reared under controlled conditions. The experiments were performed in incubators in which both temperature and photoperiod could be adjusted (humidity $40-60 \%$ ). Light intensity measured in the center was $8 \mathrm{~W} \mathrm{~m}^{-2}$ (4 Osram fluorescent tubes L18W; 220V; type: daylight). The progeny from each wild female was divided into subsamples and reared under different photoperiods but at a constant temperature. About 25 larvae from each female were kept until they pupated in a plastic box $(10 \times 10 \times 8 \mathrm{~cm})$ with a gauze lid and the bottom of which was lined with moistened tissue paper. Each day the boxes were cleaned and the larvae supplied with fresh cauliflower leaves.

To determine the geographical occurrence of aestivation in $P$. brassicae, the photoperiodic responses of all the southern populations were compared with those of all the other populations examined (Table 1).

To determine whether aestivation is a recently evolved trait and likely to be spread by dispersal, two excursions were made to Northern Spain, one in 1998 and one in 2000. Knowing the distribution of aestivation along Spain's east coast, expansion of the trait to the north was determined. Since $P$. brassicae is a strong migrant (Spieth et al., 1998), aestivation was expected to occur in more northern Spanish regions or in Southern France within two years.

An alternative explanation for the regional restriction of summer diapause is the genetic dominance of non-aestivation. Two different crossing experiments were undertaken to determine the potential for aestivation to invade a non-aestivating population. First, aestivating specimens from the region of Lisbon and non-aestivating butterflies from Denmark or Southern France were crossed. The photoperiodic response curve of the hybrids was recorded and the ratio of aestivation to hibernation was used as an indicator of dominance.

In a second study, the extent to which aestivation may ingress into populations was examined. Two inbreeding lines were reared, one with the "aestivation" trait and the other the "nonaestivation" trait. Only specimens that showed the appropriate response were paired and used to provide a series of generations. The magnitude of stepwise increase in the response is a measure for heritability. For the statistical analysis, the method for threshold characters was used (Falconer \& Mackay, 2003). Heritability is calculated using

$$
h^{2}=\frac{t}{r} \text { where } t=\frac{x_{P}-x_{R}}{i} .
$$

The subscripts $P$ and $R$ refer to parental population and relatives, respectively; $x$ is the normal deviation of the threshold from the mean, and $i$ is the intensity of selection (tabular value). In this experiment $r=1$ (both parents are "affected").

\section{RESULTS}

\section{Summer diapause}

In all of the populations of $P$. brassicae investigated for a photoperiodic response, only those from the Iberian Peninsula responded by undergoing a summer diapause (Table 1). In three populations, Castellón, Sotogrande and Lisbon, all specimens aestivated. This is depicted in Fig. 1 , together with the results for all the other populations investigated. This figure shows, that populations from Italy, Israel and Armenia did not aestivate, even though 
TABle 1. Photoperiodic responses in populations of Pieris bassicae from different localities. Listed is the critical day length (CDL) for the induction of diapause at particular temperatures. Data without references refer to unpublished results. The indices of the localities refer to the areas from which they were collected, which are depicted in Fig. 1.

\begin{tabular}{|c|c|c|c|}
\hline Locality & Geographical position & Critical day length & Reference \\
\hline Leningrad $^{1}$ & $60^{\circ} \mathrm{N} / 30^{\circ} \mathrm{E}$ & $14.5 \mathrm{~h} / 23^{\circ} \mathrm{C}$ & Danilevskii, 1965 \\
\hline Leningrad & & $15 \mathrm{~h} / 18^{\circ} \mathrm{C}$ & Maslennikova, 1959 \\
\hline Brest $^{2}$ & $52^{\circ} \mathrm{N} / 24^{\circ} \mathrm{E}$ & $14.5 \mathrm{~h} / 23^{\circ} \mathrm{C}$ & Danilevskii, 1965 \\
\hline Belgorod $^{3}$ & $50^{\circ} \mathrm{N} / 36.5^{\circ} \mathrm{E}$ & $14.5 \mathrm{~h} / 23^{\circ} \mathrm{C}$ & Danilevskii, 1965 \\
\hline Belgorod & & $15 \mathrm{~h} / 18^{\circ} \mathrm{C}$ & Maslennikova \& Mustafayeva, 1971 \\
\hline Sukhumi ${ }^{4}$ & $43^{\circ} \mathrm{N} / 41^{\circ} \mathrm{E}$ & $12 \mathrm{~h} / 18^{\circ} \mathrm{C}$ & Maslennikova, 1959 \\
\hline Kuba $^{5}$ & $41^{\circ} \mathrm{N} / 48^{\circ} \mathrm{E}$ & $13 \mathrm{~h} / 18^{\circ} \mathrm{C}$ & Maslennikova \& Mustafayeva, 1971 \\
\hline Jerevan ${ }^{6}$ & $40^{\circ} \mathrm{N} / 45^{\circ} \mathrm{E} *$ & $13 \mathrm{~h} / 18^{\circ} \mathrm{C}$ & Maslennikova \& Mustafayeva, 1971 \\
\hline Horsens ${ }^{7}$ & $56^{\circ} \mathrm{N} / 10^{\circ} \mathrm{E}$ & $16 \mathrm{~h} / 20^{\circ} \mathrm{C}$ & Spieth, 1985 \\
\hline Flensburg ${ }^{8}$ & $55^{\circ} \mathrm{N} / 10^{\circ} \mathrm{E}$ & $15.5 \mathrm{~h} / 20^{\circ} \mathrm{C}$ & \\
\hline Woodstown $^{9}$ & $52^{\circ} \mathrm{N} / 7^{\circ} \mathrm{W}$ & $15.5 \mathrm{~h} / 20^{\circ} \mathrm{C}$ & \\
\hline Anglian Heights ${ }^{10}$ & $52^{\circ} \mathrm{N} / 0.5^{\circ} \mathrm{E}$ & $14.5 \mathrm{~h} / 20^{\circ} \mathrm{C}$ & Spieth, 1985 \\
\hline Bielefeld ${ }^{11}$ & $52^{\circ} \mathrm{N} / 8.5^{\circ} \mathrm{E}$ & $15 \mathrm{~h} / 20^{\circ} \mathrm{C}$ & \\
\hline Würzburg ${ }^{12}$ & $50^{\circ} \mathrm{N} / 10^{\circ} \mathrm{E}$ & $15 \mathrm{~h} / 20^{\circ} \mathrm{C}$ & \\
\hline Schwäbisch Gmünd ${ }^{13}$ & $49^{\circ} \mathrm{N} / 10^{\circ} \mathrm{E}$ & $15 \mathrm{~h} / 20^{\circ} \mathrm{C}$ & Spieth, 1985 \\
\hline Bodensee $^{14}$ & $47.5^{\circ} \mathrm{N} / 9^{\circ} \mathrm{E}$ & $14.5 \mathrm{~h} / 20^{\circ} \mathrm{C}$ & Spieth, 1985 \\
\hline Karawanken ${ }^{15}$ & $46.5^{\circ} \mathrm{N} / 15.5^{\circ} \mathrm{E} *$ & $15.5 \mathrm{~h} / 20^{\circ} \mathrm{C}$ & Spieth, 1985 \\
\hline Livorno $^{16}$ & $43.5^{\circ} \mathrm{N} / 10^{\circ} \mathrm{E}$ & $12 \mathrm{~h} / 20^{\circ} \mathrm{C}$ & \\
\hline Giglio ${ }^{17}$ & $42^{\circ} \mathrm{N} / 10^{\circ} \mathrm{E}$ & $11.5 \mathrm{~h} / 20^{\circ} \mathrm{C}$ & \\
\hline Policastro ${ }^{18}$ & $40^{\circ} \mathrm{N} / 15.5^{\circ} \mathrm{E}$ & $-/ 20^{\circ} \mathrm{C}$ & \\
\hline Banyuls ${ }^{19}$ & $42.5^{\circ} \mathrm{N} / 3^{\circ} \mathrm{E}$ & $12 \mathrm{~h} / 20^{\circ} \mathrm{C}$ & Spieth, 1985 \\
\hline Comillas & $43^{\circ} \mathrm{N} / 4^{\circ} \mathrm{W}$ & $11 \mathrm{~h} / 20^{\circ} \mathrm{C}+$ & \\
\hline Lequeitio & $43^{\circ} \mathrm{N} / 2.5^{\circ} \mathrm{W}$ & $11 \mathrm{~h} / 20^{\circ} \mathrm{C}+$ & \\
\hline Jaca $^{20}$ & $42.5^{\circ} \mathrm{N} / 1.5^{\circ} \mathrm{E} *$ & $11 \mathrm{~h} / 20^{\circ} \mathrm{C}$ & \\
\hline Gerona $^{21}$ & $42^{\circ} \mathrm{N} / 3^{\circ} \mathrm{E}$ & $10.5 \mathrm{~h} / 20^{\circ} \mathrm{C}$ & \\
\hline Vilafranca & $41^{\circ} \mathrm{N} / 1.5^{\circ} \mathrm{E}$ & $11 \mathrm{~h} / 20^{\circ} \mathrm{C}+$ & \\
\hline Castellon ${ }^{22}$ & $40^{\circ} \mathrm{N} / 0^{\circ} \mathrm{E}$ & $-/ 21^{\circ} \mathrm{C}++$ & \\
\hline Sotogrande ${ }^{23}$ & $36.5^{\circ} \mathrm{N} / 5^{\circ} \mathrm{W}$ & $-/ 21^{\circ} \mathrm{C}++$ & Held \& Spieth, 1999 \\
\hline Sotogrande & $36.5^{\circ} \mathrm{N} / 5^{\circ} \mathrm{W}$ & $12.5 \mathrm{~h} / 17^{\circ} \mathrm{C}++$ & Held \& Spieth, 1999 \\
\hline Lisboa $^{24}$ & $38.5^{\circ} \mathrm{N} / 9^{\circ} \mathrm{W}$ & $11.5 \mathrm{~h} / 18^{\circ} \mathrm{C}++$ & Spieth et al., 2004 \\
\hline$\left(\right.$ Tel Aviv) ${ }^{25}$ & $32^{\circ} \mathrm{N} / 35^{\circ} \mathrm{E}$ & & Benyamini, 1996; Klein, 1932 \\
\hline
\end{tabular}

$(++)$ Populations in which all individuals aestivated under long-day conditions; (+) Populations in which not all individuals aestivated under long-day conditions; $\left(^{*}\right)$ high altitude areas ; $(-)$ No CDL can be quoted because under short-day conditions a high rate of non-diapause development is obligate for these populations at the temperatures cited; $\left({ }^{25}\right)$ For Tel Aviv both authors exclude aestivation; CDL not detected.

they occur at the same latitude as Castellón, or even further south.

The northern borderline of the populations undergoing summer diapause runs along the southern slopes of the Pyrenees. To the south there is a transition zone in which there are populations with different fractions of aestivating individuals (Fig. 2). On Spain's east coast, this corridor extends for about $200 \mathrm{~km}$ and is spatially very stable. In 1998, no aestivation was recorded $\left(\mathrm{n}_{\text {pupae }}=124\right.$; $\mathrm{n}_{\text {pairs }}=7$ ) for individuals that originated from the region around Gerona and were reared under long-day conditions of L/D 15/9 h. Two years later, the situation had not changed $\left(\mathrm{n}_{\text {pupae }}=529 ; \mathrm{n}_{\text {pairs }}=18\right)$ (Fig. 2$)$, despite the fact that in $1998,70 \mathrm{~km}$ south of Gerona (near Vilafranca), $35 \%\left(\mathrm{n}_{\text {pupae }}=330 ; \mathrm{n}_{\text {pairs }}=16\right)$ of the population underwent summer diapause. If a northward dispersion of this trait had occurred, the aestivation response would have reached Gerona within this period, since $P$. brassicae is a migrant species and has 4-5 generations per year in Northern Spain (Spieth, 2002). In contrast, the fraction of individuals that aestivated at Vilafanca decreased to $9 \%$ $\left(\mathrm{n}_{\text {pupae }}=624 ; \mathrm{n}_{\text {pairs }}=18\right)$ from 1998 to 2000 .

In other regions there was an opposite trend. In 1998, no aestivation was recorded near Jaca $\left(\mathrm{n}_{\text {pupae }}=198 ; \mathrm{n}_{\text {pairs }}=\right.$ $10)$ in the foot hills of the Pyrenees. Two years later, 30 $\mathrm{km}$ away from Jaca, at Nueno $11 \%\left(\mathrm{n}_{\text {pupae }}=639 ; \mathrm{n}_{\text {pairs }}=\right.$ $14)$ and in nearby Lerga $36 \%\left(\mathrm{n}_{\text {pupae }}=111 ; \mathrm{n}_{\text {pairs }}=5\right)$ of the $P$. brassicae population aestivated (Fig. 2). This indicates that the fraction of individuals in the transition zone that aestivate underlies stochastic changes.

On the east coast of the Iberian Peninsula, the transition zone seems to have shifted southward. An extensive collecting tour near Castellón, carried out in 2004, recorded only $64 \%\left(n_{\text {pupae }}=1036\right)$ in aestivation compared to $100 \%$ $\left(\mathrm{n}_{\text {pupae }}=90 ; \mathrm{n}_{\text {pairs }}=4\right)$ in 1996 . The dynamics within the transition zone is also indicated by the high deviation in this trait between progeny of different females. In 2004, 35 females from Castellón reproduced under laboratory conditions. They produced batches of eggs from which the larvae all underwent aestivation as in 1998 but also batches from which only $7 \%$ (mean $64 \%$, SD $=29.3 \%$ ) 


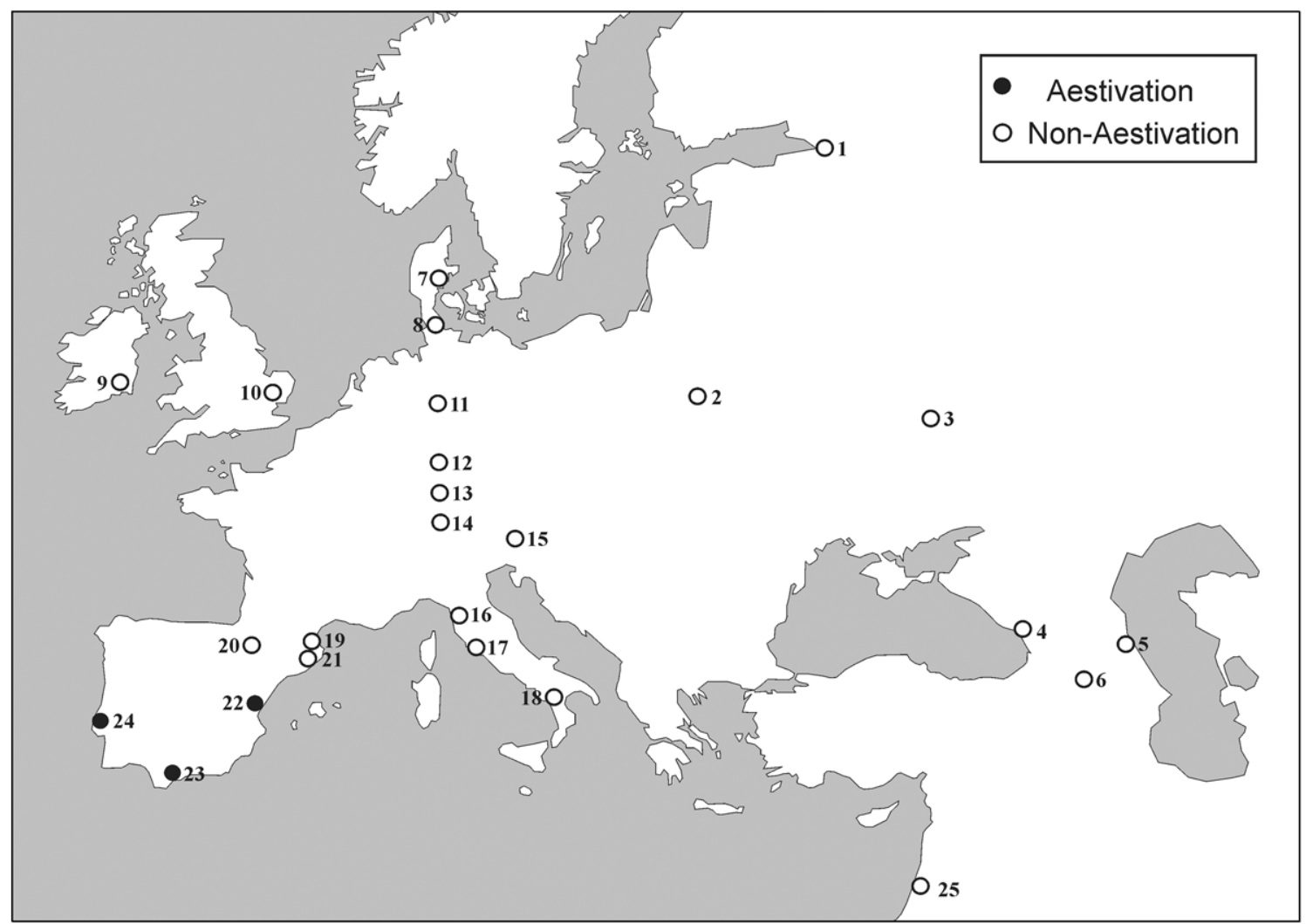

Fig. 1. The populations of Pieris brassicae for which there is information on their tendency to undergo diapause. Open circles indicate pure hibernation, filled circles hibernation plus aestivation. The numbers associated with each geographical position refer to particular critical day length conditions cited in Table 1.

aestivated . This result mirrors the dynamics of introgression and selection processes in this zone.

\section{Hybridisation and inbreeding experiments}

To determine how fast aestivation is likely to become established in a population in the absence of natural counter-selection, a situation was simulated in which butterflies from South Western Europe were mated with nonaestivating mates from northern regions. In the first experiment, butterflies from Lisbon (L) were crossed with those from Horsens (D), in Denmark (see Fig. 1 and Table 1). The Danish butterflies all underwent hibernation diapause when exposed to day lengths of $<15 \mathrm{~h}$ and the critical day length of this trait was $16 \mathrm{~h}$ (Fig. 3). Those from Lisbon showed no hibernation when reared at $21^{\circ} \mathrm{C}$, but all pupae underwent aestivation diapause at photophases $>15 \mathrm{~h}$. The critical day length for this trait was $14 \mathrm{~h}$. The diapause response of the F1 generation was similar to that of the Danish parents. In this first experiment results from reciprocal crosses were not differentiated. Non-aestivation was clearly dominant over aestivation with only a few progeny undergoing summer diapause (max. $10 \%$ at $18 \mathrm{~h}$ of light); however, the photoperiodic response curve of the hybrids was shifted to shorter photophases and the critical day length was $14 \mathrm{~h}$ rather than the $16 \mathrm{~h}$ recorded for their Danish parents. This means that the Lisbon parents had a strong influence on the hibernation response of their progeny, as they caused a shift in the response curve relative to the day length axis, whereas aestivation, the outstanding feature of the southern populations, was either not or only scarcely present.

In the second experiment, butterflies from Lisbon were hybridized with butterflies from Banyuls-sur-Mer in South Eastern France, $50 \mathrm{~km}$ north of Gerona and about $1500 \mathrm{~km}$ south of Horsens. In contrast to the butterflies from the Horsens and Lisbon populations, those from Banyuls did not undergo diapause when reared at photophases from $12 \mathrm{~h}$ to $18 \mathrm{~h}$ at $21^{\circ} \mathrm{C}$ (Fig. 4). It is known that this population does not aestivate and hibernation diapause depends strongly on temperature (Spieth, 1985). In contrast to the first experiment, the F1 hybrids showed a photoperiodic response intermediate between that of their parents. When the results of this mating were examined in greater detail, separating parent pairs by sex and origin (i.e. males from France and females from Lisbon and vice versa), it is clear that females had a stronger influence on the aestivation response than males. If females originated from Southern France (L $\times$ F; 5 pairs), a maximum incidence of aestivation in F1 of $20 \%$ was recorded when they were reared at a photophase of $15.5 \mathrm{~h}$. This value did not change with increase in photophase. If females originated from Lisbon ( $\mathrm{F} \times \mathrm{L} ; 10$ pairs), the fraction of aestivating individuals in $\mathrm{F} 1$ increased continuously, from $0 \%$ at a $14 \mathrm{~h}$ to $70 \%$ at a $18 \mathrm{~h}$ photophase.

The conclusion drawn from these two experiments is that the genetic precondition for aestivation decreases from the Iberian Peninsula towards the north. 


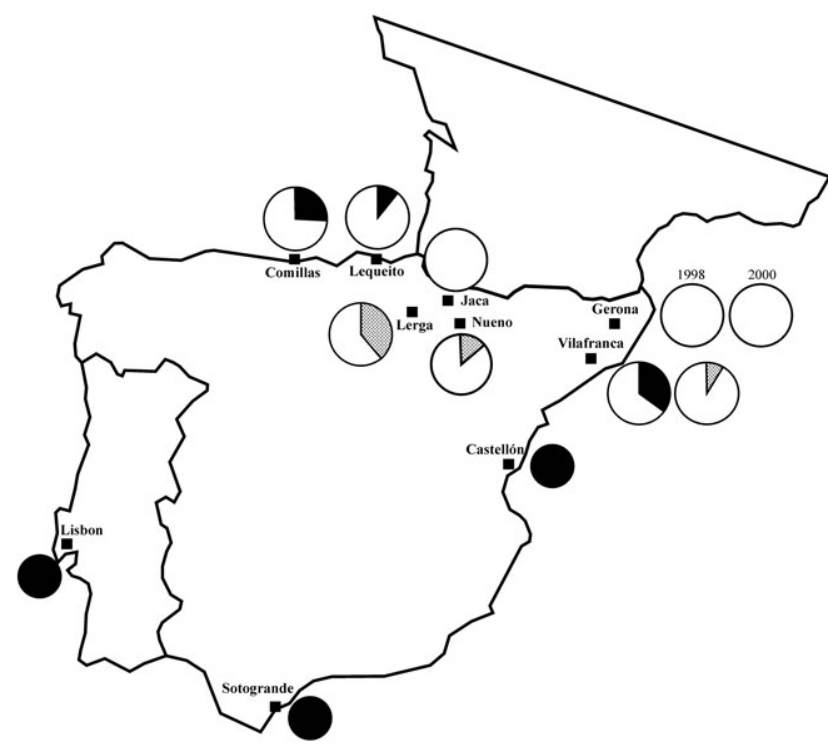

Fig. 2. Incidence of aestivation in populations on the Iberian Peninsula showing the transition zone to only hibernation in Northern Spain. The localities of the collections made in 1998 and 2000 are indicated. The fraction of individuals that aestivated in 1998 is depicted in black and in grey for 2000. The populations from Castellón, Sotogrande and Lisbon (smaller circles) were tested before 1998 .

A further approach to investigating the heritability of aestivation was to inbreed lines with specific response types (Fig. 5). The breeding lines for the traits "aestivation" and "non-aestivation" were started with populations responding with $18 \%(\mathrm{n}=93)$ of aestivation or $8 \%(\mathrm{n}=$ 68) of non-aestivation, respectively. Both traits exhibited high heritability. In the "non-aestivation" line, it varied in the different generations, ranging from $h^{2}=0.52$ to $h^{2}=$ 0.73 . In the "aestivation" line, the heritability was weak from the parental generation to $\mathrm{F} 1\left(\mathrm{~h}^{2}=0.21\right)$ but in subsequent generations it was similar to that recorded for the non-aestivation line, with values ranging from $h^{2}=0.35$

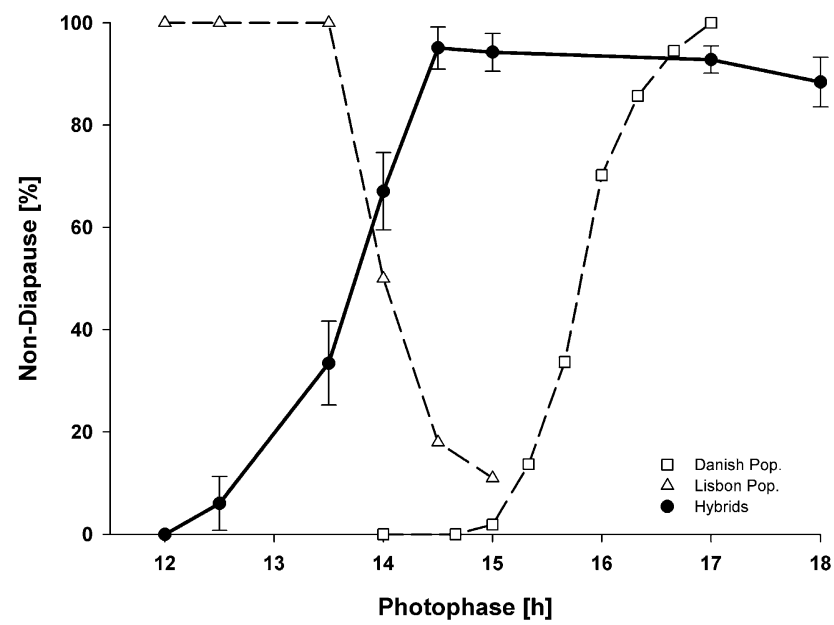

Fig. 3. Incidence of non-diapause among hybrids resulting from crossing individuals from different geographical origins. Individuals from Denmark, which do not aestivate were mated at $21^{\circ} \mathrm{C}$ with individuals from Lisbon. Error bars represent the SE. Number of individuals per data point: $\mathrm{n}_{\max }=165, \mathrm{n}_{\min }=110$.

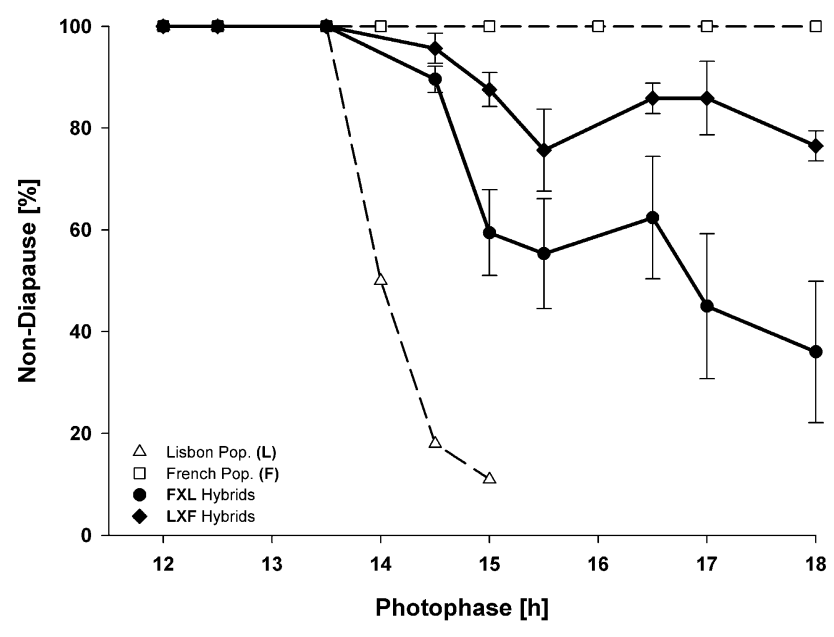

Fig. 4. Incidence of non-diapause among hybrids resulting from crossing individuals from different geographical origins. Individuals from France $(\mathrm{F})$, which do not aestivate, were mated at $21^{\circ} \mathrm{C}$ with individuals from Lisbon $(\mathrm{L})$. The crosses were between French males and Lisbon females $(\mathrm{F} \times \mathrm{L})$ and the reverse $(L \times F)$. Error bars represent the SE. Number of individuals per data point: $\mathrm{n}_{\max }=188, \mathrm{n}_{\min }=30$; mean $=91 \pm 43$.

to $h^{2}=0.77$. Therefore, the heritability of aestivation in this species is similar to that of non-aestivation.

\section{DISCUSSION}

For more than half a century, the large white butterfly has been used as a model organism in different fields of biological research. This well known species is a classical example of a multivoltine species, which undergoes hibernation diapause (see Table 1) induced by day lengths, which is dependent on the geographical location of the population. In 1999, Held \& Spieth discovered that this species exhibits an additional photoperiodic response in Southern Spain: a photoperiodically induced summer diapause. Nowhere else in its wide distribution area does this butterfly show this response (Fig. 1). Therefore, the

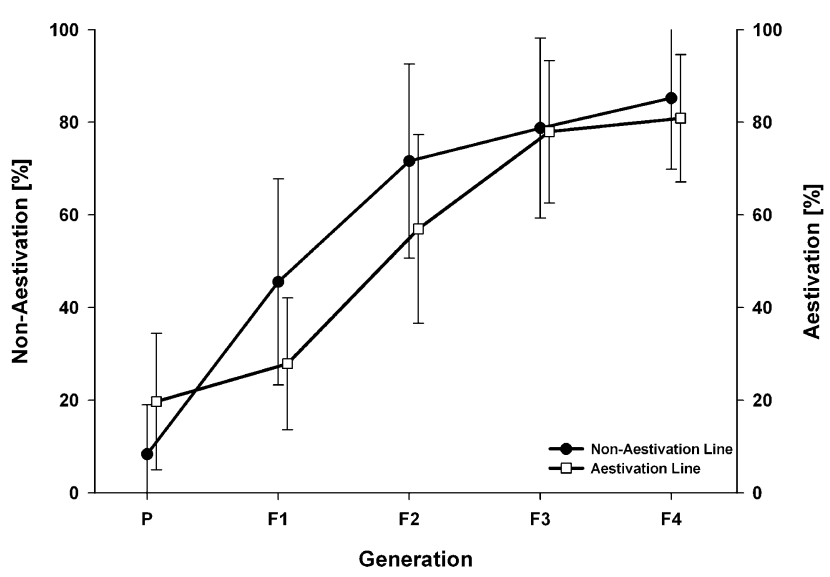

Fig. 5. The results of starting with two different parental generations $(\mathrm{P})$, and inbreeding over four generations (F1-F4) for, in one case "aestivation", and in the other "non-aestivation". Only individuals that aestivated (aestivation line) or did not aestivate in each generation were mated. Rearing condition were $20^{\circ} \mathrm{C}$ and $16 \mathrm{~h}$ light. Error bars represent the SD. 
question arose: Why does it undergo summer diapause only on the Iberian Peninsula?

Pieris brassicae is a typical migratory butterfly (Williams, 1958; Roer, 1959; Baker, 1978), escaping adverse seasonal conditions by migration. Hence this species normally has two strategies for surviving unfavourable conditions: (1) Migration (the summer option) and (2) hibernation (the winter option). Why $P$. brassicae in South Western Europe has evolved a third strategy is unclear. Moreover, it is important to understand why the aestivation trait has not spread into other hot and dry areas. The answer may lie, at least in part, in the nature of the inheritance of this trait. The results presented, indicate a weak introgression of the aestivation trait into populations from Northern Europe, and its expression in the F1 hybrids is negligible (Fig. 3). This differs from the results of crosses between aestivating individuals and specimens from adjacent populations in Southern France, which indicate that the aestivation trait is intermediately inherited and has a strong effect on the diapause response of the progeny depending on the origin of females (Fig. 4). In- and outbreeding experiments for the trait "hibernation" or "aestivation", respectively, led to an elimination of the competing response within 4-5 generations (Fig. 5). These results exclude the possibility of genetic mechanisms restricting the occurrence of summer diapause to South Western Europe.

Aestivation is not a trait that has recently evolved in this region or been introduced from elsewhere into South Western Europe. If it were a new trait, it would be expected to disperse quickly northward, since this butterfly regularly migrates, e.g. between Spain and France (personal communication of Constanti Stefanescu). In 1998 the borderline for the aestivation response was along the southern slopes of the Pyrenees (Fig. 2). Two years later, it had not moved. This is especially clear in North Eastern Spain, since around Gerona no aestivation was detected in either year despite the geographically very close occurrence of aestivating individuals $(70 \mathrm{~km}$ south of the city). If the aestivation trait were adaptive in this region, it would have reached Gerona easily within two years, i.e. after $8-10$ generations. The conclusion is that aestivation has no adaptive value for this species beyond the northern borderline.

This raises the question of the benefit of summer diapause in this region. There is evidence for two alternative but not mutually exclusive hypotheses. The caterpillars of $P$. brassicae are heavily attacked by a parasitoid, the braconid Cotesia glomerata, whose life cycle is co-adapted to its main host, $P$. brassicae. The percentage parasitism in the first two generations each year is low then it increases and may be very high in certain areas, and in extreme cases 100\% (Feltwell, 1982). Although the life cycles of the parasitoid and host are normally synchronized, the parasitoid in Southern Spain, unlike its host, does not aestivate (Spieth \& Schwarzer, 2001). If the host undergoes summer diapause, as is the case in South Western Europe, a decisive element in the successful reproduction of $C$. glomerata is absent for about three months (June-August). This results in the parasitoid switching to other, lesser suitable hosts, and a consequent decrease in the local abundance of the parasitoid. The benefit for $P$. brassicae is that in September, after its summer rest, it is less heavily parasitized (Pörschmann \& Spieth, 2011).

This undoubtedly positive effect for $P$. brassicae is presumably only adaptive in areas where the climatic conditions remain favourable and the butterfly produces many generations per year. In two subsequent years, in the coastal region near Lisbon $P$. brassicae produced its first adult generation as early as January / February. An assessment of the number of generations occurring in South Western Europe, using local climatic data and different developmental parameters of the large white butterfly (Spieth, 2002), revealed that nine generations per year are theoretically possible. Because of summer diapause, the potential is reduced to six generations per year, three in spring and three in autumn. However, the situation changes in Northern Spain. The first generation adults emerge in the middle of March, the last generation adults in September / October. The butterfly can only complete five generations in the climatic conditions prevailing in Northern Spain. If these butterflies aestivated their life history would be reduced to two generations per season, in which case the cost of aestivation may exceed that of parasitism. Hence, summer diapause may not be adaptive for populations that complete fewer generations than populations in Southern Europe; therefore, it is unlikely that this trait will spread into the central European area.

An alternative hypothesis accounting for the evolution of aestivation in South Western Europe is that the synchronisation of the generations by hibernation diapause is not possible under the prevailing climatic conditions in that area and that this is achieved by summer diapause. Winter diapause physiologically ends after a few months in mid-winter (Koštál, 2006) and post-diapause development is induced when certain temperature thresholds are reached. The minimum temperature for development in $P$. brassicae lies in the range of $8-10^{\circ} \mathrm{C}$. The mean winter temperature in Southern Spain does not fall below $12^{\circ} \mathrm{C}$. Because of this, the time spent in winter diapause varies greatly. Short days may induce the first diapausing pupae in October, but many individuals of that generation produce a further generation that does not pupate before midDecember (Spieth, 2002). The hibernating pupae that develop in October are ready for emergence in January / February, when the December pupae are physiologically still in deep diapause. Therefore, hibernation can not synchronize the development of this butterfly in South Western Europe; rather, this process is achieved by aestivation. All butterflies emerge synchronously each year, after aestivation in August / September, no matter which life history they exhibit prior to the summer arrest. Accordingly, summer diapause is only adaptive in multivoltine species living under these specific climatic conditions. 
It is not possible to determine whether a reduction in the level of parasitism or synchronization of the generation sequence is the main driving force behind the development of summer diapause in South Western Europe based on current knowledge. Both hypotheses only hold for populations that occur in areas where a favourable climate and a very long growing season enable the butterfly to produce many generations per year. The lack of these preconditions in most the regions within P. brassicae's distribution explains both the absence of aestivation in many regions and the prevention of the dispersal of this trait to other regions. Nonetheless, it is proposed that aestivation would be adaptive in other regions with similar conditions, provided that individuals with the ability to aestivate find their way there.

\section{REFERENCES}

BAKER R.R. 1978: The Evolutionary Ecology of Animal Migration. Hodder \& Stoughton, London, $1012 \mathrm{pp}$.

Beck S.D. 1980: Insect Photoperiodism. 2nd ed. Academic Press, New York, 387 pp.

Benyamini D. 1996: Pupal summer diapause in Chilean Pieris brassciae (Linnaeus, 1758) (Lepidoptera, Pieridae). Nota Lepidopt. 18: 184-192.

Bradshaw W.E. \& Holzapfel C.M. 2007: Evolution of animal photoperiodism. Annu. Rev. Ecol. Evol. Syst. 38: 1-25.

DANILEVSKII A.S. 1965: Photoperiodism and Seasonal Development of Insects. Oliver and Boyd, Edinburgh/London, 283 pp.

Danks H.V. 1987: Insect Dormancy. An Ecological Perspective. Biological Survey of Canada, Ottawa, 439 pp.

DANKS H.V. 2001: The nature of dormancy responses in insects. Acta Soc. Zool. Bohem. 65: 169-179.

DANKS H.V. 2002: The range of insect dormancy responses. Eur. J. Entomol. 99: 127-142.

DANKs H.V. 2006a: Key themes in the study of seasonal adaptations in insects II: life-cycle patterns. Appl. Entomol. Zool. 41: $1-13$.

DANKs H.V. 2006b: Insect adaptation to cold and changing environments. Can. Entomol. 138: 1-23.

FALCONER D.S. \& MACKAY T.F.C. 2003: Introduction to Quantitative Genetics. 4th ed. Pearson, Harlow, $464 \mathrm{pp}$.

Feltwell J. 1982: Large White Butterfly, the Biology, Biochemy and Physiology of Pieris brassicae (Linnaeus). Dr. W. Junk Publishers, The Hague-Boston-London, 535 pp.

GomI T. 1997: Geographic variation in critical photoperiod for diapause induction and its temperature dependence in Hyphantria cunea DRURY (Lepidoptera: Arctiidae). Oecologia 111: 160-165.

GrÜNER C. \& MASAKi S. 1994: Summer diapause in the polymorphic life cycle of the noctuid moth Mamestra brassicae. In Danks H.V. (ed.): Insect Life-Cyle Polymorphism. Theory, Evolution, and Ecological Consequences for Seasonality and Diapause Control. Kluwer Academic Publishers, Dordrecht, pp. 191-204.

GrÜNer C. \& Sauer K.P. 1988: Aestival dormancy in the cabbage moth Mamestra brassicae L. (Lepidoptera: Noctuidae). 1. Adaptive significance of variability of two traits: Day length thresholds triggering aestival dormancy and duration of aestival dormancy. Oecologia 74: 515-523.

Held C. \& SPIETH H.R. 1999: First evidence of pupal summer diapause in Pieris brassicae L.: The evolution of local adaptiveness. J. Insect Physiol. 45: 587-598.
Hodek I., Окuda T. \& Hodkova M. 1984: Reverse photoperiodic responses in two subspecies of Coccinella septempunctata L. Zool. Jb. Syst. 111: 439-448.

KLEIN H.Z. 1932: Studien zur Ökologie und Epidemiologie der Kohlweißlinge. I. Der Einfluß der Temperatur und Luftfeuchtigkeit auf Entwicklung und Mortalität von Pieris brassicae L. Z. Angew. Entomol. 19: 395-488.

KošŤÁL V. 2006: Eco-physiological phases of insect diapause. $J$. Insect Physiol. 52: 113-127.

MASAKI S. 1968: Geographic adaptation in the seasonal life cycle of Mamestra brassicae (Linné) (Lepidoptera: Noctuidae). Bull. Fac. Agric. Hirosaki Univ. 14: 16-26.

Masaki S. 1980: Summer diapause. Annu. Rev. Entomol. 25: $1-25$.

MASAKI S. 1996: Geographical variation of life cycle in crickets (Ensifera: Grylloidae). Eur. J. Entomol. 93: 281-302.

MasLENNIKova V.A. 1959: The relationship of the seasonal development of Apanteles glomeratus L. to that of its host Pieris brassicae L. in different geographical populations. Entomol. Rev. 38: 463-467.

Maslennikova V.A. \& Mustafayeva T.M. 1971: An analysis of photoperiodic adaptions in geographic populations of Apanteles glomeratus (Hymenoptera, Braconidae) and Pieris brassicae (Lepidoptera, Pieridae). Entomol. Rev. 50: 281-284.

Musolin D.L. \& SAulich A.H. 1999: Diversity of seasonal adaptations in terrestrial true bugs (Heteroptera) from the temperate zone. Entomol. Sci. 2: 623-639.

Numata H. 2004: Environmental factors that determine the seasonal onset and termination of reproduction in seed-sucking bugs (Heteroptera) in Japan. Appl. Entomol. Zool. 39: 565-573.

Pörschmann U. \& Spieth H.S. 2011: Aestivation in Pieris brassicae L. affects the parasitoid load caused by Cotesia glomerata L. Entomol. Sci. 14: 31-36.

RoER H. 1959: Über die Flug- und Wandergewohnheiten von Pieris brassicae. Z. Angew. Entomol. 44: 272-309.

SAUER K.P. \& GRÜNER C. 1988: Aestival dormancy in the cabbage moth Mamestra brassicae L. (Lepidoptera: Noctuidae). 2. Geographical variation in two traits. Oecologia 76: 89-96.

SPIETH H.R. 1985: Die Anpassung des Entwicklungszyklus an unterschiedlich lange Vegetationsperioden beim Wanderfalter Pieris brassicae L. (Lepidoptera: Pieridae). Zool. Jb. Syst. 112: 35-69.

SPIETH H.R. 1995: Change in photoperiodic sensitivity during larval development of Pieris brassicae. J. Insect Physiol. 41: 77-83.

SPIETH H.R. 2002: Estivation and hibernation of Pieris brassicae (L.) in Southern Spain: synchronization of two complex behavioral patterns. Popul. Ecol. 44: 273-280.

Spieth H.R. \& Schwarzer E. 2001: Aestivation in Pieris brassicae (Lepidoptera: Pieridae): Implications for parasitism. Eur. J. Entomol. 98: 171-176.

Spieth H.R. \& Strauss K. 2010: Photosensitivity a disregarded attribute to analyze "Photoperiodic Clocks". In Salvenmoser O. \& Meklau B. (eds): Biological Clocks: Effects on Behavior, Health and Outlook. Nova Science Publishers, Hauppauge, NY, pp. 39-72.

Spieth H.R., Cordes R.G. \& Dorka M. 1998: Flight direction in the migratory butterfly Pieris brassicae: Results from seminatural experiments. Ethology 104: 339-352.

Sieth H.R., Xue F.S. \& Strauss K. 2004: Induction and inhibition of diapause by the same photoperiod: experimental evidence for a "double circadian oscillator clock". J. Biol. Rhythms 19: 483-492. 
TAKEDA M. 1997: Effects of photoperiod and temperature on larval development and summer diapause in two geographic ecotypes of the rice stem maggot, Chlorops oryzae MATSUMURA (Diptera: Chloropidae). Appl. Entomol. Zool. 32: 63-74.

Tauber M.J., Tauber C.A. \& Masaki S. 1986: Seasonal Adaptations of Insects. Oxford University Press, New York/Oxford, $411 \mathrm{pp}$.

Veerman A. 1992: Diapause in phytoseiid mites: a review. Exp. Appl. Acarol. 14: 1-60.

Wang X.P., Xue F.S., Tan Y.Q. \& Lei C.L. 2007: The role of temperature and photoperiod in diapause induction in the brassica leaf beetle, Phaedon brassicae (Coleoptera: Chrysomelidae). Eur. J. Entomol. 104: 693-697.
Wiklund C., Persson A. \& Wickman P.O. 1983: Larval aestivation and direct development as alternative strategies in the speckled wood butterfly, Pararge aegeria, in Sweden. Ecol. Entomol. 8: 233-228.

Williams C.B. 1958: Insect Migration. Collins, London, 235 pp. Xue F.S., Kallenborn H.G. \& Wei H.Y. 1997: Summer and winter diapause in pupae of the cabbage butterfly, Pieris melete Ménétriés. J. Insect Physiol. 43: 701-707.

Xue F.S. \& Kallenborn H.G. 1998: Control of summer and winter diapause in Pidorus euchromioides (Lepidoptera: Zygaenidae) on Chinese sweetleaf Symplocos chinesis. Bull. Entomol. Res. 88: 207-211.

Zaslavski V.A. 1988: Insect Development. Photoperiod and Temperature Control. Springer, Berlin, 188 pp.

Received October 19, 2010; revised and accepted November 30, 2010 